\title{
ПАТОФІЗІОЛОГІЧНО ОБҐРУНТОВАНА РЕСПІРАТОРНА ТЕРАПІЯ ПНЕВМОНІЙ, СПРИЧИНЕНИХ SARS-COV-2
}

\author{
Г.П. Хитрий, О.В. Рабощук
}

Українська військово-медична академія, м. Київ

\begin{abstract}
Вступ. Близько 5 \% пацієнтів з COVID-19 перебувають у критичному стані. Більшість з них потребують апаратної підтримки або повного заміщення функції легень.

Метою роботи $\epsilon$ розгляд діючих тимчасових рекомендації ВООЗ та інші літературних джерел, що стосуються респіраторної підтримки пацієнтів з COVID-19. Висвітлення особливостей патофбізіологічно обгрунтованого підходу до вибору параметрів респіраторної терапії пневмоній, спричинених SARS-CoV-2.

Матеріали та методи. Матеріалами дослідження стали рекомендації всесвітньовідомих організацій, задіяних до боротьби з пандемією COVID-19, а також матеріали публікацій, які узагальнюють міжнародний досвід лікування вірусних пневмоній. Методи дослідження - бібліосемантичний, аналітичний.

Результати. У статті розглянуто дискутабельні питання респіраторної підтримки пацієнтів 3 COVID-19. Наведено альтернативний погляд італійських дослідників на існування принципово відмінних фенотипів пневмоній, спричинених SARS-CoV-2. Обгрунтовано патофізіологічні зміни в дихальній системі, які визначають наявність різних фенотипів пневмоній при COVID-19. Особлива увага приділена диференційованому підбору параметрів респіраторної терапії пневмоній, спричинених SARS-CoV-2, відповідно до фенотипу даної патології.
\end{abstract}

Висновки. виділено основні аспекти патофізіологічно обгрунтованого підходу до респіраторної терапії пневмоній, спричинених SARS-CoV-2. Сформульовано практичні рекомендації по підбору окремих параметрів штучної вентиляції легень у пацієнтів з COVID-19.

Ключові слова: COVID-19, пневмонія, спричинена SARS-CoV-2, фенотип пневмонії, пацієнтіндуковане пошкодження легень, респіраторна терапія, позитивний тиск кіния видиху.

Вступ. Спалах коронавірусної інфекції COVID-19 (пневмонія нового типу), спричинена коронавірусом SARS-CoV-2, розпочався в кінці грудня 2019 року в м. Ухань центрального Китаю. 31 грудня 2019 року влада Китаю поінформувала про спалах невідомої пневмонії Всесвітню Організацію Охорони здоров'я (В003). 11 лютого 2020 року захворювання отримало назву нової коронавірусної пневмонії (COVID-2019), до цього воно іменувалося 2019-nCoV. Згодом китайські вчені виділили новий коронавірус - SARS-CoV-2 - і встановили генетичну послідовність його геному.

Хоча у більшості людей з COVID-19 спостерігається неускладнений або легкий перебіг захворювання (81\%), у деяких зустрічається тяжкий перебіг захворювання, яке потребує оксигенотерапії (14\%), і приблизно в 5\% випадків потрібне лікування у відділенні реанімації та інтенсивної терапії (BPIT). Більшості пацієнтам, які перебувають у критичному стані, потрібне проведення штучної вентиляції легень (ШВЛ) $[1,2]$. Найбільш частим діагнозом у пацієнтів 3 тяжким перебігом інфекції COVID-19 є пневмонія тяжкого ступеню, спричинена коронавірусом SARS-CoV-2.

Інкубаційний період пневмонії нового типу триває від 2 до 28 днів, і, згідно з останніми даними, захворювання стає заразним до появи симптомів. 30 січня 2020 року на засіданні комітету 3 надзвичайних ситуацій В0О3 спалах нового коронавірусу був визнаний надзвичайною ситуацією у сфері охорони здоров'я, що має міжнародне значення.

Особливо небезпечною $є$ інфекція COVID-19 у пацієнтів похилого віку (> 65 років) із супутніми захворюваннями, яка може призвести до тяжких і навіть смертельних захворювань органів дихання, таких як гострий респіраторний дистрес-синдром (ГРДС) [3]. Смертність пацієнтів з пневмонією SARS-CoV-2, які поступають в критичному стані, залишається високою. Серйозність пневмонії SARS-CoV-2 має велике навантаження на ресурси BPIT в лікарнях, особливо якщо вони не адекватно укомплектовані або забезпечені [1].

Від початку пандемії COVID-19 опубліковано ряд керівництв та рекомендацій щодо особливостей респіраторної терапії у пацієнтів з даним захворюванням. Через брак часу для 
проведення якісних досліджень та узагальнення їх результатів переважна більшість рекомендацій мають низький рівень доказовості. Найбільшого поширення набули тимчасові рекомендації ВОО3 - «Клінічне ведення тяжкої гострої респіраторної інфекції при підозрі на коронавірусну інфекцію COVID-19» від 13 березня 2020 р. [4].

Мета роботи. Розглянути діючі тимчасові рекомендації В003 та інші літературні джерела, що стосуються респіраторної підтримки пацієнтів з COVID-19. Висвітлити особливості патофізіологічно обгрунтованого підходу до вибору параметрів респіраторної терапії пневмоній, спричинених SARS-CoV-2.

Матеріали та методи дослідження. Матеріалами дослідження $\epsilon$ рекомендації всесвітньовідомих організацій, задіяних до боротьби з пандемією COVID-19, а також матеріали публікацій, які узагальнюють міжнародний досвід лікування вірусних пневмоній. Методи дослідження - бібліосемантичний, аналітичний.

Результати дослідження та їх обговорення. Згідно вище зазначених рекомендацій В003 для пацієнтів з середньотяжким та тяжким пошкодженням легень, що обумовлені новим коронавірусом SARS-CoV-2, під час проведення респіраторної терапії рекомендуються більш високі значення позитивного тиску кінця видиху (ПТКВ) у порівнянні з низькими [4]. Паралельно з накопиченням досвіду лікування коронавірусної інфекції збільшилась кількість повідомлень про неефективність застосування високого ПТКВ у деяких пацієнтів з COVID-19 та пов'язаний з цим підвищений ризик виникнення ускладнень $[5,6]$. Автори пояснюють це відмінностями при певних варіантах перебігу пневмоній, спричинених SARS-CoV-2, від типового ГРДС. Так, для частини пацієнтів з COVID-19 характерний розвиток значної гіпоксемії при збереженому комплаєнсі легеневої тканини на відміну від типового ГРДС, при якому комплаєнс легень майже завжди значно знижений [5]. Gattinoni L. et al. виділяють два принципово відмінні фенотипи пневмоній при COVID-19 [6]. Фенотип L (від англ. Low низький), для якого характерні низький еластанс (тобто майже збережений комплаєнс), низьке співвідношення вентиляція / перфузія, низька рекрутабельність. Фенотип Н (від англ. High - високий) характеризується на противагу фенотипу L високими значеннями усіх вище перерахованих показників. Крім того, фенотип L властивий для більш ранніх стадій ураження легень та з прогресуванням захворювання може трансформуватися у фенотип Н.

Більш детально перебіг захворювання за фенотипом L описується наступними патофізіологічними змінами у дихальній системі:

- низький еластанс (майже нормальний комплаєнс), що свідчить про нормальне або незначно порушене заповнення альвеол повітрям;

- низький коефіцієнт вентиляція / перфузія, оскільки вентиляція альвеол майже не страждає, гіпоксія може бути пояснена порушенням регуляції легеневого кровотоку, а саме втратою гіпоксичної вазоконстрикції;

- низька рекрутабельність легень (неефективність рекрутмент маневру пояснюється відносно малою кількістю колабованих альвеол). ГРДС [6].

При фенотипі Н патологічні зміни в легенях цілком відповідають критеріям тяжкого

Вище наведені відмінності вказують на те, що різні фенотипи пневмоній, спричинених SARS-CoV-2, потребують патофізіологічно обгрунтованих підходів до респіраторної підтримки. Експерти В0О3 рекомендують починати лікування дихальної недостатності з інгаляції кисню та поступово нарощувати респіраторну підтримку в залежності від відповіді пацієнта на здійснені заходи. Так, якщо інгаляція зволоженого кисню не призвела до бажаного результату, слід перейти до високопотокової інгаляції кисню, неінвазивної ШВЛ. Якщо й ці заходи не мали успіху, слід своєчасно перевести хворого на інвазивну ШВЛ [4].

Хоча автори настійно застерігають від необгрунтованих затримок з інтубацією трахеї, однак наступні запитання залишаються й досі відкритими: коли необхідно вчасно переводити хворого з пневмонією, обумовленою SARS-CoV-2, на інвазивну ШВЛ; чому відтермінування 3 інтубацією трахеї асоціюється з негативними наслідками лікування? Для отримання відповідей на ці запитання необхідно знову повернутися до патофізіології різних фенотипів пневмоній при COVID-19. Прогресування пневмонії від фенотипу L до фенотипу Н зумовлене зростанням 
негативного внутрішньогрудного інспіраторного тиску, яке $\epsilon$ наслідком форсування самостійного дихання пацієнтом у відповідь на гіпоксемію. При цьому на тлі запального підвищення проникності легеневих капілярів додаткове зниження внутрішньогрудного тиску призводить до набряку альвеол [6]. Дане явище отримало назву пацієнт-індукованого пошкодження легень (ПІПЛ).

3 часом посилений набряк збільшує масу легень, тиск і ателектазування. Коли набряк легень досягає певної величини, зменшуються об'єм газу в легені та дихальний об'єм. На цій стадії розвивається задишка, що зі свого боку призводить до погіршення ПІПЛ. Розвиток ПІПЛ можна попередити шляхом інтубації трахеї та своєчасного переведення пацієнта на інвазивну вентиляцію легень $[7,8]$. Проте не слід забувати, що відхилення від стратегії протективної ШВЛ, погана синхронізація апарату ШВЛ з пацієнтом так само можуть призвести до ще більш небезпечного пошкодження легеневої тканини [9]. Gattinoni L. et al. стверджують, що ризик ПІПЛ можна оцінити шляхом вимірювання внутрішньостравохідного тиску, який відображає внутрішньогрудний тиск [10]. Автори рекомендують негайно проводити інтубацію трахеї при коливаннях внутрішньостравохідного тиску більше 15 см $\mathrm{H}_{2} \mathrm{O}$, так як це $є$ маркером загрози ПІПЛ [6]. На жаль, методика моніторингу внутрішньостравохідного тиску є недоступною у більшості лікувальних закладів України. В цих умовах лікар повинен запідозрити ризик розвитку ПІПЛ у пацієнтів з надмірно форсованим вдихом та значними коливаннями ЦВТ при зміні фаз дихального циклу [11].

Також широко дискутується підбір правильних значень ПТКВ у пацієнтів з COVID-19. Існує твердження, що застосування ПТКВ знижує транспульмональний градієнт, тобто різницю внутрішньоальвеолярного та внутрішньоплеврального тисків і усуває дію головного пошкоджуючого фактору ПІПЛ - зростання негативного внутрішньогрудного інспіраторного тиску [6, 7]. Тому використання методів респіраторної підтримки, які підвищують ПТКВ (неінвазивна ШВЛ, високопотокова оксигенація), може бути дієвим у пацієнтів з фенотипом L. Проте застосування ПТКВ більше 8 - 10 см $\mathrm{H}_{2} \mathrm{O}$ у даної категорії пацієнтів (фенотип L) при інвазивній ШВЛ видається більш небезпечним, ніж корисним. Оскільки високий ПТКВ при низькій рекрутабельності, характерній фенотипу L, скоріше матиме негативний вплив на гемодинаміку без покращення оксигенації [12]. Отже, лікар повинен розсудливо обирати значення ПТКВ в залежності від фенотипу пневмоній, спричинених SARS-CoV-2.

Що ж стосується підходу до респіраторної терапії пацієнтів з пневмонією фенотипу Н, то він цілком відповідає загальноприйнятій стратегії лікування тяжкого ГРДС з високими значеннями ПТКВ $[13,14]$.

\section{Висновки}

1. У ряді випадків патологічні зміни в легенях, спричинені коронавірусом SARS-CoV-2, значно відрізняються від пошкоджень легень при типовому ГРДС.

2. Доцільно виділяти два фенотипи пневмоній, спричинених SARS-CoV-2: фенотипи L та H, які потребують принципово різних підходів до респіраторної підтримки.

3. Застосування методів неінвазивної ШВЛ при пневмонії фенотипу L видається раціональним з позиції попередження розвитку ПІПЛ та трансформації захворювання у фенотип Н.

4. При прийнятті рішення про переведення пацієнта з COVID-19 на інвазивну ШВЛ слід керуватися об'єктивними даними про ризик виникнення ПІПЛ.

5. Застосування високих значень ПТКВ (більше 8 - $10 \mathrm{~cm} \mathrm{H}_{2} \mathrm{O}$ ) на початку респіраторної терапії пацієнтів з пневмонією фенотипу L $€$ невиправданим та небезпечним через низьку рекрутабельність легень.

6. Респіраторна терапія пацієнтів з пневмонією фенотипу Н відповідає принципам лікування типового ГРДС з високими значеннями ПТКВ. 


\section{References}

\section{Література}

1. Clinical course and outcomes of critically ill patients with SARS-CoV-2 pneumonia in Wuhan, China: a single-centered, retrospective, observational study / Yang X, Yu Y, Xu J, Shu H, Xia J, Liu H et al. // Lancet Respir Med. - 2020. - Epub 2020/02/28. doi: 10.1016/S2213-2600(20)30079-5. PubMed PMID: 32105632.

2. Wu Z, McGoogan JM. Characteristics of and important lessons from the coronavirus disease 2019 (COVID-19) outbreak in China: summary of a report of 72314 cases from the Chinese Center for Disease Control and Prevention // JAMA. - 2020. - Epub 2020/02/25. doi: 10.1001/jama.2020.2648. PubMed PMID: 32091533.

3. Epidemiological and clinical characteristics of 99 cases of 2019 novel coronavirus pneumonia in Wuhan, China: a descriptive study / Chen N, Zhou M, Dong X, et al. // Lancet. - 2020. - Vol. 395. - P. 507-513.

4. World Health Organization. (2020). Clinical management of severe acute respiratory infection (SARI) when COVID-19 disease is suspected: interim guidance, 13 March 2020. - Режим доступу до ресурсу: https://apps.who.int/iris/handle/10665/331446.

5. Covid-19 does not lead to a "typical" acute respiratory distress syndrome / Gattinoni L. et al. // American journal of respiratory and critical care medicine. - 2020. - Режим доступу до ресурсу: https://www.atsjournals.org/doi/pdf/10.1164/rccm.202003-0817LE

6. COVID-19 pneumonia: different respiratory treatments for different phenotypes? / Gattinoni L. et al. // Intensive care medicine. - 2020. - Режим доступу до ресурсу: https://link.springer.com/article/10.1007/s00134-020-06033-2

7. Patient self-inflicted lung injury: implications for acute hypoxemic respiratory failure and ARDS patients on non-invasive support / Grieco D. L. et al. // Minerva Anestesiol. - 2019. - Vol. 85. - № 9. - P. 10141023.

8. Patient self-inflicted lung injury and positive end-expiratory pressure for safe spontaneous breathing / Yoshida T. et al. // Current opinion in critical care. - 2020. - Vol. 26. - № 1. - P. 59-65.

9. Beitler J. R., Malhotra A., Thompson B. T. Ventilator-induced lung injury // Clinics in chest medicine. 2016. - Vol. 37. - № 4. - P. 633-646.

10. Targeting transpulmonary pressure to prevent ventilator-induced lung injury / Gattinoni L. et al. // Expert review of respiratory medicine. - 2019. - Vol. 13. - № 8. - P. 737-746.

11. Walling P. T., Savege T. M. A comparison of oesophageal and central venous pressures in the measurement of transpulmonary pressure change // British journal of anaesthesia. - 1976. - Vol. 48. - № 5. - P. 475-479.

12. Luecke T. Clinical review: positive end-expiratory pressure and cardiac output // Critical Care. 2005. - Vol. 9. - № 6. - P. 607-621.

13. Intensive care management of coronavirus disease 2019 (COVID-19): challenges and recommendations / Phua J. et al. // The Lancet Respiratory Medicine. - 2020. - № 8. - P. 506-517.

14. Surviving Sepsis Campaign: guidelines on the management of critically ill adults with Coronavirus Disease 2019 (COVID-19) / Alhazzani W. et al. // Intensive care medicine. - 2020. - Режим доступу до ресурсу: https://www.researchgate.net/publication/340255377 Surviving Sepsis Campaign guidelines on the manage ment of critically ill adults with Coronavirus Disease 2019 COVID-19.

\section{ПАТОФИЗИОЛОГИЧЕСКИ ОБОСНОВАННАЯ РЕСПИРАТОРНАЯ ТЕРАПИЯ ПНЕВМОНИЙ, ВЫЗВАННЫХ SARS-CoV-2}

\section{Г.П. Хитрый, А.В. Рабощук}

Украинская военно-медицинская академия, Киев

Введение. Около 5\% пациентов с COVID-19 находятся в критическом состоянии. Большинство из них требуют аппаратной поддержки или полного замещения функции легких.

Целью работы является рассмотрение действующих временных рекомендаций ВОЗ и других литературных источников, касающихся респираторной поддержки пациентов с COVID-19. Иллюстрация особенностей патофизиологически обоснованного подхода к выбору параметров респираторной терапии пневмоний, вызванных SARS-CoV-2.

Материалы и методы. Материалами исследования стали рекомендации всемирно-известных организаций, задействованных в борьбе с пандемией COVID-19, а также материалы публикаций, обобщающих международный опыт лечения вирусных пневмоний. Методы исследования библиосемантический, аналитический.

Результаты. В статье рассмотрены дискутабельные вопросы респираторной поддержки пациентов с COVID-19. Приведен альтернативный взгляд итальянских исследователей на существование 
принципиально отличающихся фенотипов пневмоний, вызванных SARS-CoV-2. Обосновано патофизиологические изменения в дыхательной системе, которые определяют наличие различных фенотипов пневмоний при COVID-19. Особое внимание уделено дифференцированному подбору параметров респираторной терапии пневмоний, вызванных SARS-CoV-2, в соответствии с фенотипами данной патологии.

Выводы. Выделены основные аспекты патофизиологически обоснованного подхода $к$ респираторной терапии пневмоний, вызванных SARS-CoV-2. Сформулированы практические рекомендации по подбору отдельных параметров искусственной вентиляции легких у пациентов с COVID-19.

Ключевые слова: COVID-19, пневмония, вызванная SARS-CoV-2, фенотип пневмонии, пациентиндуцированное повреждение легких, респираторная терапия, положительное давление конца выдоха.

\section{PATHOPHYSIOLOGY-BASED RESPIRATORY THERAPY OF PNEUMONIA CAUSED BY SARS-CoV-2}

\section{G.P. Khytryi, O.V. Raboshchuk}

Ukrainian military medical academy,Kyiv

Introduction. About 5\% of patients with COVID-19 are in critical condition. Most of them need hardware support or complete replacement of lung function.

Purpose of the study: to review the current WHO interim guideline and other literature sources on respiratory support for patients with COVID-19. Elucidation of the features of pathophysiology-based approach to the choice of parameters of respiratory therapy of pneumonia caused by SARS-CoV-2.

Materials and methods. The materials of the study were the recommendations of world-renowned organizations involved in the fight against the COVID-19 pandemic, as well as materials of publications that summarize the international experience in the treatment of viral pneumonia. Research methods - bibliosemantic, analytical.

Results. The article discusses the controversial issues of respiratory support of patients with COVID-19. An alternative view of Italian researchers on the existence of fundamentally different phenotypes of pneumonia caused by SARS-CoV-2 is given. Pathophysiological changes in the respiratory system, which determine the presence of different phenotypes of pneumonia in COVID-19, are substantiated. Particular attention is paid to the differentiated selection of parameters of respiratory therapy of pneumonia caused by SARS-CoV-2, according to the phenotype of this pathology.

Conclusions. Highlight the main aspects of the pathophysiology-based approach to respiratory therapy of pneumonia caused by SARS-CoV-2. Practical recommendations for the selection of individual parameters of artificial lung ventilation in patients with COVID-19 are formulated.

Key words: COVID-19, SARS-CoV-2 pneumonia, pneumonia phenotype, patient-induced lung injury, respiratory therapy, positive end-expiratory pressure.

Конфлікт інтересів: відсутній.

Conflicts of interest: authors have no conflict of interest to declare.

$A$ - концепція та дизайн дослідження; B - збір даних; $C$ - аналіз та інтерпретація даних; D написання статmi; $E$ - редагування статmi; F- остаточне затвердження статті

\section{Відомості про авторів:}

Хитрий Г.П., E F полковник медичної служби, доктор медичних наук, професор, начальник кафедри анестезіології та реаніматології Української військово-медичної академії м. Київ;

Рабощук О.В., ${ }^{A-B} C D$ капітан медичної служби, викладач кафедри анестезіології та реаніматології Української військово-медичної академії м. Київ.

Сведения об авторах:

Хитрый Г.П., E F полковник медицинской службы, доктор медицинских наук, професор, начальник кафедры анестезиологии и реаниматологии Украинской военно-медицинской академии, г. Киев;

Рабощук О.В., $A-B C D$ капитан медицинской службы, преподаватель кафедры анестезиологии и реаниматологии Украинской военно-медицинской академии, г. Киев .

Information about authors:

Khytryi G.P., E F Col. MS, MD DSc, Prof., Head of the Department of Anesthesiology and Intensive Care of the Ukrainian Military Medical Academy, Kyiv ORCID ID 0000-0002-7888-1771;

Raboshchuk O.V., ${ }^{A-B C D}$ Capt. MS, Teacher of the Department of Anesthesiology and Intensive Care of the Ukrainian Military Medical Academy, Kyiv ORCID ID 0000-0002-0408-2651. 